\title{
Working
}

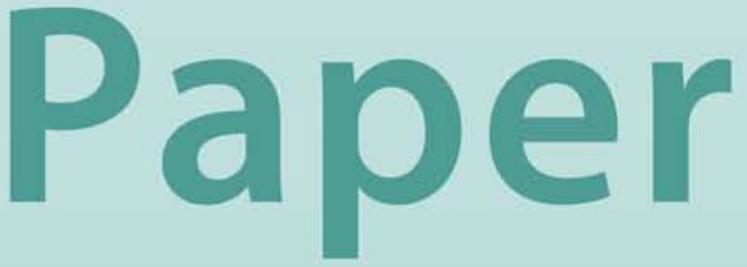




\section{Demographic Transition in the Middle East: Implications for Growth, Employment, and Housing}

Pierre Dhonte, Rina Bhattacharya, and Tarik Yousef 


\title{
IMF Working Paper
}

\author{
Middle Eastern Department
}

\section{Demographic Transition in the Middle East: Implications for Growth, Employment, and Housing}

Prepared by Pierre Dhonte, Rina Bhattacharya, and Tarik Yousef ${ }^{\text {t }}$

March 2000

\begin{abstract}
The views expressed in this Working Paper are those of the author(s) and do not necessarily represent those of the IMF or IMF policy. Working Papers describe research in progress by the author(s) and are published to elicit comments and to further debate.
\end{abstract}

The working age population is expected to grow faster in the Middle East than in any other region in the world between now and 2015-rising annually by 2.7 percent, or 10 million people. This demographic explosion presents the region with a major challenge in terms of providing jobs, incomes, and housing for the growing population, but the expanding labor force can also be seen as an opportunity to generate higher per capita income growth on a sustainable basis. The paper concludes by emphasizing the importance of market-friendly institutions in turning the challenge into opportunity.

JEL Classification Numbers: 015, 040

Keywords: demography, growth, housing

Author's E-Mail Address: pdhonte@imf.org, rbhattacharya@imf.org, youseft@gunet.georgetown.edu

${ }^{1}$ The authors wish to thank Eduard Bos, David Burton, Paul Chabrier, Zubair Iqbal, and Karim Nashashibi for comments and suggestions, and Ilse-Marie Fayad and Binta Terrier for research assistance. 


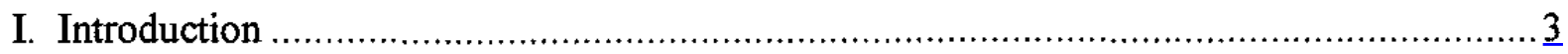

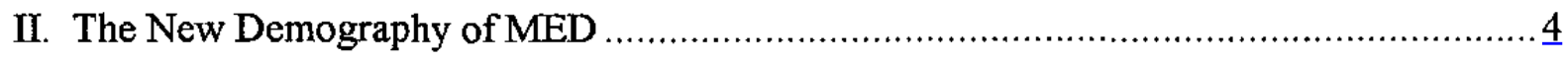

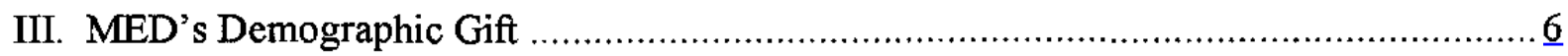

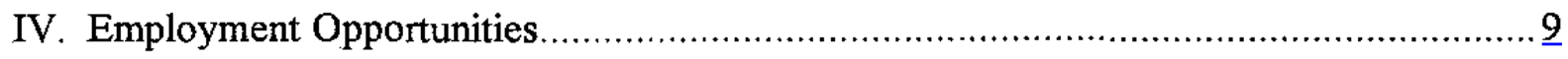

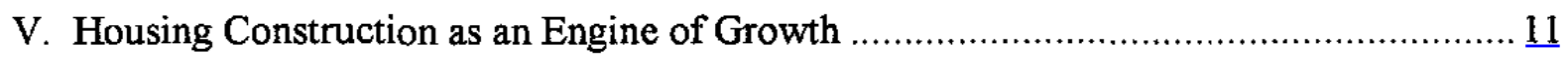

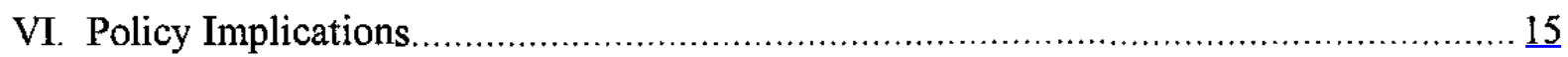

Tables

1. Selected Regions: Key Population Data, 1970, 2000, 2015 .................................. 17

2. Selected Regions: Age Structure of the Population, 1970, 2000, 2015 ................. 18

3. Selected MED Countries: Employment, 1973-2015 ....................................... 19

4. Selected MED Countries: The Augmented Demographic Gift ............................... 20

5. Selected MED Countries: Total Factor Productivity Growth Requirements ................. 21

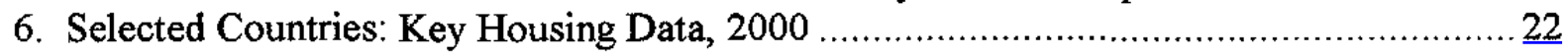

Boxes

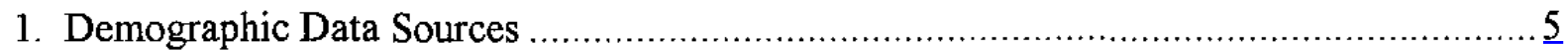

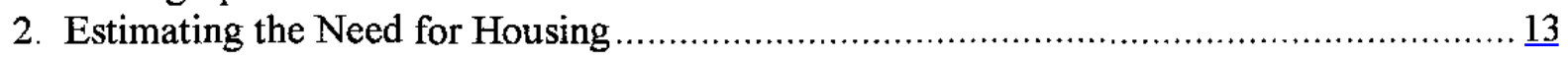

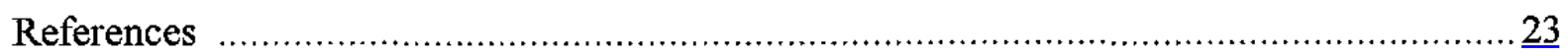




\section{INTRODUCTION}

The population of the Middle East has grown very rapidly in the past three decades, faster than all regions in the world except sub-Saharan Africa. ${ }^{2}$ This demographic explosion went hand in hand with an expanded labor force, increased urbanization and rural-urban migration, and a rising gap in food self-sufficiency. Yet, for much of the period rapid population growth was of little concern to policymakers. Regional economies were undergoing rapid structural transformation and GDP growth performance was above the average of developing countries. Moreover, the state expanded its role as employer and consumer, and the oil boom stimulated substantial flows of labor and capital within the region.

In the aftermath of the oil bust in the mid-1980s and the Gulf War in 1990, economic growth has decelerated in most countries in the region. In response, governments have pursued reform efforts aimed at liberalizing their economies and generating faster growth. Notwithstanding progress in trade reform and financial liberalization, structural adjustment has been slow, and the dominance of the public sector continues to be evident throughout the region; in many countries, the private sector has yet to become an engine of economic transformation.

The labor markets of the region, despite an enviable record of employment creation, remain burdened by high rates of unemployment, partly the result of existing distortions and the legacy of the role of the state as the main employer. Moreover, over the next two decades, the dynamics of demographic transition will generate growing pressures as the population age structure matures; indeed, the region's working age population is forecast to grow faster than any other region in the world between now and 2015 , at an annual rate of 2.7 percent. Employment growth rates in excess of 4 percent per annum will need to be sustained to absorb this growing population, allow for rising participation rates, and reduce unemployment. Accordingly, the region's key economic challenge is to accelerate economic growth through rapid accumulation and enhanced efficiency to absorb large numbers of new workers in jobs that ensure sustained increases in real wages, while labor market rigidities and biases in the educational systems are addressed.

This paper highlights selected aspects of this challenge. Following the introduction, the rest of the paper is organized as follows: Section II provides an overview of recent demographic trends in the region, emphasizing the maturing age structure and rapid rise in the share of the working age population; Section III highlights the potential positive contribution of this "demographic gift" to the process of accumulation and GDP growth; Section IV embeds the demographic projections through 2015 into a growth accounting framework and carries out

${ }^{2}$ Throughout this paper, unless otherwise stated, "Middle East countries" will refer to the countries of the Arab League (the "Arab countries") as well as Pakistan, the Islamic State of Afghanistan, and the Islamic Republic of Iran ("PAI"), which together comprise the area of the Fund's Middle Eastern Department (MED). 
simulations of labor market conditions; Section V shows the wide-reaching implications of the new demography for the housing construction sector; and by way of conclusion, Section VI points to the broader implications for economic policy.

\section{THE NEW DEMOGRAPHY OF MED ${ }^{3}$}

The populations of the two groups of countries comprising MED are comparable in size, present demographic characteristics, and projected demographic trajectory. The population of the Arab countries numbers about 280 million, that of Pakistan, Afghanistan, and Iran (PAI) is about 240 million. In both groups of countries the "working age population" (aged 15-64) accounts for over 55 percent of the total, with the school age population the second largest group ( 40 percent), and people 65 and above a comparatively small fraction of the total (Tables 1 and 2). Similar characteristics apply to individual countries within each group.

Over the past three decades, the population of these two groups has been growing rapidly. It more than doubled from 223 million in 1970 to 545 million by 2000 and is projected to rise to 720 million by 2015 . Such rates of increase vastly exceed those in the rest of the world or in any of its major regions, including south Asia; only Africa comes close. As a result, the population of MED countries will rise from 6 percent of the world total in 1970 to over 10 percent in 2015 , and the region will be home to one in seven of the world's new babies over the next 15 years. However, population growth will ease in the $21^{\text {st }}$ century. Already, fertility rates have experienced a sharp decline in a number of countries and the overall growth rates are projected to decelerate gradually over the next 25 years.

Equally significant, the demography of MED will be shaped by the trends in age structure: the expanding bulge in the middle and the shrinking younger tail in the age distribution of the population. The share of the working age group in the total population has been rising from 52 percent in 1970 to 57 percent today, a trend that is projected to accelerate in the next decade so that the ratio exceeds 62 percent by 2015 (Table 2). Such a trend is expected and conforms to observed patterns across the world. For the world as a whole, the working age population was 63 percent of the total in 2000 and is expected to rise to 67 percent in 2015 . Thus, in fact, the ratio is still relatively low in MED countries, and will continue to expand for decades to come.

${ }^{3}$ Demographic data for this paper are drawn from the World Development Report Database (1999), supplemented by additional data from the World Bank. Data for 2000 and 2015 are projections based on a baseline scenario; the sensitivity of the scenarios to alternative assumptions for fertility and mortality rates would not affect materially the points of emphasis here. For details on the sources and the projections, see Box 1. 


\section{Box 1. Demographic Data Sources}

There are two main sources of cross-country data on demography, namely the World Development Report (WDR) and the United Nations Population Division.

The demographic data in the WDR is based on the most recent official figures, usually individual country census results supplemented by official estimates for years immediately following the census. Only in a few countries (such as Saudi Arabia) where there is no recent population census, or where the census results yield implausible figures, does the WDR rely on estimates from the UN Population Division. For example, the 1999 WDR demographic data on Algeria are official estimates from the National Statistical Agency, the Office National de Statistique, based on preliminary results from the 1998 census; the data for Iran are based on the results of the 1996 census and official estimates from the Statistical Centre of Iran; the Moroccan and Tunisian data are based on the results of 1994 censuses, supplemented by official estimates to 1998. In the case of Egypt, the 1996 census results have been adjusted using estimates of the number of Egyptians living abroad, and supplemented by World Bank projections for subsequent years. Likewise, in the case of Jordan the results of the 1994 census are combined with World Bank projections for more recent years. The World Bank projections make use of a cohort-component method, which project age-specific fertility and mortality schedules based in part on recent country-specific trends in these variables and on life tables that provide projected life expectancy and infant mortality rates.

There are two main sources of discrepancy between the WDR and the UN demographic data and projections. The UN Population Division data in some cases do not reflect the latest available information--such as, in the case of Jordan, the results of the 1997 Population and Family Health Survey - because they place more emphasis on consistency of data across countries (for example, that the global net migration figures add up to zero). By contrast the WDR concentrates more on the individual country data and projections, and on incorporating the latest available information for each country.

The second main source of discrepancy between the WDR and the UN are country-specific. For example, in the case of Jordan the UN figures incorporate the West Bank and Gaza, whereas the WDR data do not. 
In combination, the high total population growth rates and rapidly changing age structure entail extremely high rates of growth of the working age population-a compound growth rate in excess of 3 percent over the half century from 1970! To put this in perspective, the working age population of MED countries was half that of the European Union (EU) (15) in 1970; it will be almost twice as large in 2015 . While its growth rate will fall over time, the absolute numbers will rise strongly; new entrants to the working age group will average 15 million a year over the next 15 years, while the net increase (allowing for aging and mortality) will average 10 million a year.

Moreover, employment will need to grow even faster than the working age population. Employment needs will be boosted by rising labor participation rates and by the objective of reducing current unemployment rates. Table 3 projects employment needs for the period 2000-2015, assuming a uniform contribution (1 point) from rising participation rates and a halving of the unemployment rate by the end of the projection period (except for Pakistan where the initial rate is low). The calculations suggest that, over the next 15 years, employment in the seven countries will need to rise on average by an astounding compound growth rate of over 4 percent, with a "low" target of 3.6 percent in the Arab Republic of Egypt, Morocco, and Tunisia, and a "high" figure of 5.0 percent in Algeria. ${ }^{4}$ In all countries, the growth of the working age population provides by far the greatest contribution to the targeted employment growth. Such employment growth requirements are much higher than those registered in the fastest job-creating regions of East Asia and the Caribbean and Latin America, where employment grew over the period 1990-97 on average by 2.3 percent and 2.9 percent per annum, respectively. ${ }^{5}$ This development moreover is a new trend for the region. In all countries the needs for employment growth are strongly in excess of recent performance. The strongest acceleration in the rate of employment growth would be required in Algeria and Egypt, where it would be around 2 percent per annum.

\section{MED'S DEMOGRAPHIC GIFT}

What are the consequences of demographic changes for long-run per capita GDP growth? Early studies of this relationship have yielded no unambiguous correlations; results tended to hinge on the sample, the time period, and the choice of explanatory variables. The recent revival of the life-cycle model and its incorporation into empirical studies of cross-country

\footnotetext{
${ }^{4}$ Due to data uncertainties and methodological difficulties, historical estimates of output and employment are subject to a wide margin of error and should only be regarded as indications of broad trends. More generally, the reference to individual countries in this and the following sections of the paper is meant to convey the diversity of experiences; it is not meant to make factual or normative statements about the individual country.

${ }^{5}$ Data on employment growth are from the ILO database. See Guasch (1999) for an exposition of trends and determinants of job creation in Latin America in the 1990s.
} 
growth has renewed interest in this link. ${ }^{6}$ Recent empirical studies have emphasized the importance of demographic transitions, the process of moving from pre-industrial conditions of high fertility and high mortality to the post-industrial conditions of low fertility and low mortality. They suggest that what matters for economic growth is not the rate of population growth per se, but rather the changing age-distribution of populations as countries pass through demographic transitions. ${ }^{7}$ When a large share of the population is young and nonworking, an economy carries a demographic burden that lowers labor input per capita, depresses the savings rate, and reduces the rate of GDP per capita growth. This was the case in Asia and Latin America in the 1950s and 1960s. Conversely, countries are endowed with a demographic gift when, following with a lag the decline in fertility, a larger share of the population is of working age, raising the labor force per capita, capital accumulation and GDP per capita growth - as was the case in Asia during the miracle years of the 1970 s and 1980 s, East Asia in particular. In turn, a growing share of the older, nonworking population may cause a reversal of the process. Altogether, whether a country carries a demographic burden or receives a demographic gift depends on the change in the share of the working age population in the total. As shown in Table 2, MED countries stand to receive a large demographic gift in the coming period.

A rather natural augmentation of the notion of demographic gift is to focus, beyond the share of the working age population, on the ratio of employment in the total population; these two ratios differ over time due to changes in the participation rate and in unemployment. This

\footnotetext{
${ }^{6}$ See, in particular, Kelley (1988) and Kelley and Schmidt (1995) for summaries of firstgeneration studies. On the recent work that incorporates the life cycle in cross-country growth analyses, see Bloom and Williamson (1998) and Radelet, Sachs, and Lee (1997).

${ }^{7}$ In focusing on the impact of the changing age distribution of the population on economic growth, we are following a recent promising line of research that has disaggregated the impact of population growth into its components of fertility and mortality effects on economic growth (Barlow (1994); Brander and Dowrick (1994); Kelley and Schmidt (1995)). The theoretical basis of this argument relies on examining the impact of changes in the age distribution on the transitional dynamics of GDP per capita growth in a standard neoclassical growth model. The full explanation can be found in Bloom and Williamson (1998). For a diagrammatic exposition of the demographic transaction, see Crafts (1998). Bloom and Williamson (1997) have identified demography as the most important factor distinguishing the high performing east and southeast Asian economies from the slower-growing economies in South Asia. On the basis of demography alone, they attributed one half to two thirds of East Asia's superior growth performance in 1965-90 to its favorable demographic structure.
} 
augmented gift can be simply expressed in the form of a positive wedge between the growth of income per capita and that of output per employee, where the former is augmented by the increase in the employment ratio:

$$
(y-n)=(y-l)+(l-n)
$$

where $y, n$, and 1 are the growth rates of output, population, and employment, respectively.

In MED's circumstances, the growth of the working age population should be significantly augmented by increasing participation rates and by a decline in the unemployment ratio. As shown in Table 4, employment overall did not grow much faster than the population in the past two decades; by contrast, under the previously mentioned targets for unemployment and assumptions for the participation rate, it would outpace population growth by over 2 percent per annum, and in some cases close to 3 percent in the projection period. This is indeed a large and growing "augmented gift." Its significance can be brought out by noting that even a relatively unambitious real wage growth target of 1.5 percent per employee would entail a major acceleration of income growth on a per capita basis.

Combining equation (1) with an equation expressing the determinants of steady state output per worker from a standard Ramsey model, Williamson and Yousef (1999) arrive at the following equation for the growth of output per capita: ${ }^{8}$

$$
(y-n)=\alpha_{1} l+\alpha_{2} n+\sum_{i} \beta_{i} X_{i}+\varepsilon
$$

Equation (2) relaxes the parameter restrictions of equation (1) and allows for different coefficients for population growth and employment growth consistent with the dynamics of the demographic transition. Under a variety of specifications, the authors conclude that the "demographic gift" as defined above is a significant argument in regressions where real per capita GDP growth is the dependent variable, a finding that applies to all regions in the world including MED. Where the working age population grows faster than the total population, GDP per capita growth is faster. According to their estimated parameters and the projected population structure, the large demographic gift of MED countries alone would contribute 1.1 percent per annum in real GDP per capita growth over the period 2000-2015 (ceteris paribus). With the targeted labor force growth of 4.0 percent per annum, the augmented gift would contribute 2.7 percent per annum in real per capita growth over the same period.

\footnotetext{
${ }^{8}$ In addition to traditional neoclassical variables-initial conditions, measures of physical and human capital, economic openness, and political stability - the matrix $\mathrm{X}$ of variables that determine steady state growth in output per worker includes indicators that control for natural resource intensity, economic geography, government policy, and the quality of institutions.
} 


\section{EMPLOYMENT OPPORTUNTIES}

While an opportunity, the rapid expansion of the working age population presents a serious challenge: how can faster and/or more labor-intensive economic growth be facilitated to provide jobs to an expanding labor force while ensuring sustained increases in per capita income? The mechanics of the demographic gift highlighted in the previous section implicitly assume well-functioning labor and capital markets. In the absence of wellfunctioning labor markets and steady output growth, the rising working age population in the 1990 s would compound the problem of double-digit unemployment, especially among firsttime entrants into the labor force.

We use a simple growth accounting framework to highlight this question. Rather than project long-term growth potential, our goal is simply to provide plausible quantitative scenarios linking the dynamics of demography to the policy objectives of employment creation and GDP growth in the immediate future. The starting point for the exercise is a Cobb Douglas production function with increasing returns to scale in human capital:

$$
Y(t)=A(L H)^{\alpha} K^{1-\alpha} e^{\gamma t}
$$

where $Y$ is output, $L$ is labor, $H$ is the stock of human capital or "labor quality," $K$ is physical capital and $A$ is the level of technology or total factor productivity (TFP). Expressing the variables in equation ( 3 ) in terms of growth rates, the equilibrium wage condition yields the following expression for the required TFP growth, given targets for employment and the real wage and assumptions on human and physical capital accumulation: ${ }^{10}$

$$
\gamma^{*}=\bar{w}+(1-\alpha) \bar{l}-\alpha h-(1-\alpha) k
$$

The implication is that employment of the growing labor input associated with the demographic gift would not be consistent with maintained wages unless there is faster capital accumulation and/or TFP growth. ${ }^{11}$ In focusing on TFP as a policy variable, we depart from

${ }^{9}$ Although the estimated high unemployment rates for the region in the 1990 s are second only to sub-Saharan Africa, the figures are considerably higher within the age group 15-24 who are largely first-time job seekers; for example, in Algeria, the unemployment rate for this group was more than twice that of the overall labor force (Pissarides (1993)).

${ }^{10}$ We follow Collins and Bosworth (1996), who argue for the imposition of a uniform value of 0.35 for the elasticity of output with respect to growth of capital.

${ }^{11}$ This requirement however is eased by the demographic transaction itself. Recent crosscountry studies indicate that national savings/investment ratios are strongly influenced by demographic transitions: high dependency rates depress both savings and investment, while a rise in the working age population induces the opposite (Yousef (1998)). 
the more conventional approach in which a "warranted wage" growth is seen as the outcome of targets of accumulation. This restatement is in line with the now well-accepted thinking that regards government policies, both with respect to the macroeconomic environment and to the creation of institutions that foster economic growth, as an important determinant of the overall efficiency of economic activity. ${ }^{12}$

Against this background, Table 5 computes the gains in total factor productivity that are required to meet the employment needs of Table 3 and still allow real wages per employee to rise by 1.5 percent per annum, assuming a moderate investment ratio. The simulation results point to considerable differences among the countries in terms of the magnitude and the nature of the challenges involved in meeting the employment targets. In large part, this is a reflection of their differing initial conditions: ${ }^{13}$ on the one hand, Algeria and Iran, with historically weak productivity performance reflected in negative TFP growth and a high incremental capital-output ratio (ICOR); on the other, Egypt, Morocco, Pakistan, and Tunisia, who have done historically better in terms of efficiency. Within each of these groupings, countries differ historically in their investment ratio; we assume for the projection period a uniform investment ratio of 28 percent of GDP, which in some cases (Egypt, Iran, Morocco, and Pakistan) requires an additional investment effort, in other cases (Algeria) represents a slackening or (Jordan and Tunisia) a sustained effort. ${ }^{14}$

Turning first to Algeria where unemployment is currently running at around 28 percent, the working age population is expected to rise by over 2.7 percent per annum during 2000-2015 and the labor force by 3.7 percent, given the assumed rise in the participation rate. Halving the unemployment rate by end-2015 would call for employment growth of 5.0 percent and real GDP growth of 6.5 percent per annum. Given also the above assumptions for human and physical capital formation, this requires TFP growth of 0.21 percent per annum (compared with -3.4 percent per annum for the period 1973-1994), consistent with a sharp reduction in ICOR, from 12.5 to 4.3 . The strong underlying message in the case of Algeria is that greater

${ }^{12}$ Page and Van Gelder (1999) discuss the channels through which institutional capabilities affect the pace of accumulation and the allocation of resources; they note in particular the negative influence of investor perceptions on the level of private investment in the region.

13 The legacy of import-substitution policies with their emphasis on capital accumulation, historically varies across countries depending on the nature and intensity of state intervention. See Richards and Waterbury (1996) for a survey of country experience with state planning and industrialization prior to the 1990s.

${ }^{14}$ It should be noted that the required TFP performance depends on the assumed investment ratio; with the parameters used here, a difference of \pm 2.5 points in the investment ratio makes a difference - with opposite sign-of 0.3 point to the required TFP gain. 
efficiency in the use of capital, rather than increased resource accumulation, is the key to achieving high and employment-intensive growth. A similar conclusion applies in the case of Iran. Here we set a target of reducing the unemployment rate from around 14 percent at present to 7 percent by 2015 ; this in turn requires an average annual growth in employment of 4.1 percent per annum. Even if gross investment rises from 19 percent to 28 percent of GDP and human capital continues to grow at the high historical rate of 1.1 percent per annum, the ICOR must fall from 57 to 5.0, and TFP growth must improve from an estimated -3.4 percent for the period 1973-1994 to -0.3 percent per annum.

The situation is rather different in Egypt, Morocco, Pakistan, and Tunisia where halving the unemployment rate by 2015 requires employment growth of 3.6-4.0 percent per annum. With human capital growing at its historical average, there is no pressing need for faster TFP growth or for a reduction in the ICOR, assuming however in the case of Egypt and Pakistan that the investment ratio rises to 28 percent, or that they sustain their apparent strong historical record of low ICOR and high TFP growth.

While individual country situations thus differ rather markedly, the overall message is strikingly positive: given a moderately high investment effort, and a "reasonable" level of efficiency in resource use, there is scope in all countries for absorbing into employment the growing labor force and the overhang of unemployment. Whatever the possible flaws in measurement of historical performance, what matters is that the "required" level of efficiency derived in this section, and the assumed investment ratio are both well within the range of international and historical experience.

\section{Housing Construction as an ENgine of Growtit}

Where will the additional employment come from? Much attention has focused on the potential impact of trade liberalization and FDI on job creation in the region. We focus here on another channel, directly linked to the very demographic conditions that raise the issue in the first place: the demand for housing. As they have elsewhere, the new demographic conditions in the region are likely to spur a massive expansion in the housing construction sector. ${ }^{1516}$ Because housing construction is predominately a labor-intensive activity, meeting

${ }^{15}$ Mankiw and Weil (1989) have shown in the context of the U.S. baby boom generation that while an individual generates little demand for housing before the age of 20 , housing demand rises sharply between ages 20 and 30 and remains flat thereafter. Accordingly, the rise in the demand for housing and real estate prices in the 1970s were a predictable consequence of the maturing of the baby boom generation who were born in the late $1940 \mathrm{~s}$ and early $1950 \mathrm{~s}$. More recently, Lindh and Malmberg (1999) have established this link in the context of the whole OECD group.

${ }^{16}$ Sternleib and Hughes (1983) have attributed the parallel cycles in labor force growth and housing expansion to the changing age structure of the U.S. population since the $1950 \mathrm{~s}$. Our 
the demand for housing can go a long way in addressing the employment problem, providing a two-way improvement in welfare. Recent trends in the housing market in MED, especially on the supply side, are difficult to establish. On the basis of early surveys and qualitative evidence, however, there is little doubt that a substantial shortage of housing units has been building up since the late 1970 s, with disproportionate effects on young adults and the poor. ${ }^{17}$

We provide a rough approximation of the need for new housing units to give an idea of the magnitudes involved, a necessary exercise given the limited attention devoted to the housing problems in policy discussions. ${ }^{18}$ The exercise concludes that, for a group of seven MED countries (Algeria, Egypt, Iran, Jordan, Morocco, Pakistan, and Tunisia) with a total working age population of 206 million in 2000, the need for new housing is in excess of 6 million units per year, whereas deliveries are about 1 million (Box 2 and Table 6). There would exist a large potential demand, which, if it could be made effective, would provide a major boost to domestic activity.

The massive gap between need as defined in Box 2 and effective demand for housing is a major opportunity for growth in MED countries. Since housing construction typically accounts for 3 percent of GDP and 5 percent of employment in MED countries, though with a rather wide dispersion, a many-fold increase in housing deliveries would provide a major boost to employment and activity. Moreover, because housing construction is largely selffinancing, this boost would be sustainable. ${ }^{19}$

analysis follows this line of reasoning, namely that the rise in the working age population and the increase in the demand for housing are closely related.

${ }^{17}$ For example, the accumulated deficit in housing in Egypt between 1960 and 1979 was estimated at 2 million units (Mohie el-Din (1982)). In Algeria, the construction of housing units fell from 90,000 units in 1986 to 30,000 in 1991, at a time when annual demand for housing was 200,000 units (World Bank (1994)).

${ }^{18}$ We should note however that social scientists have devoted extensive attention to the political and social implications of housing shortages in MED. As Richards and Waterbury (1996) have rightly observed, the high unemployment rates and lack of affordable housing in MED in the 1990s are two intertwined problems facing young adults in the region; indeed, a healthy housing market is a reflection of well-functioning labor and credit markets.

${ }^{19}$ Available estimates of output and employment in the construction sector generally do not provide a clear breakdown between residential construction, other construction, and infrastructure and for this reason need to be treated with caution. 


\section{Box 2. Estimating the Need for Housing}

The exercise derives the potential flow demand for housing units as the sum of three components: replacement of the existing stock; reduction of the existing shortfall; and accommodation of the growing population. For comparison, a similar exercise is conducted for four industrial countries.

a. Replacement demand is assumed to be equivalent to 2.5 percent of the existing stock in MED countries, which would be consistent with a 30 -year average life of a housing unit and a 2.5 percent annual growth rate of the housing stock. Rather than a technical constraint, the replacement ratio is an economic variable, reflecting changes in the demand for quality, location, etc.; it is likely to be rather high in emerging countries, given the poor quality of important components of the existing stock, the rise in aspirations, the trend to urbanization, etc. Data in Table 6 suggest that these factors have a lesser incidence in industrial countries, where replacement demand (calculated in this case as a residual) could be only 1 percent of the housing stock, consistent with a 50-year average lifetime of a housing unit at a 2.5 percent growth rate of the housing stock.

b. In most emerging countries, the existing stock of housing is less than the desired stock, resulting in overcrowding of existing units. It is assumed here that the adjustment to the desired stock would span a 30 -year period along a geometric growth path at 5 percent per annum. The estimate for the desired housing stock itself is based on the size of working age population, which is a proxy for the number of single family households. The ratio of the housing stock to the population aged 15-64 averages 60 percent in the industrial countries of Table 6 , and this provides a convenient benchmark to estimate a desired stock for the MED economies; by construction, this estimate makes allowance for the reduction in overcrowding and assumes a gradual shift in household composition toward the single family pattern prevalent in advanced economies.

c. The third component of flow demand is the accommodation of the increase in the number of households, proxied by the growth rate of the population aged 15-64. Since adjustment to the "desired" housing conditions has been allowed for in (b) above, that growth rate applies to the desired stock of housing.

Three major conclusions flow from this exercise. First, the present rate of housing construction hardly meets 20 percent of the estimated need in the countries of Table 6 , with a particularly acute percentage shortfall in Pakistan, and a better situation in Tunisia. Second, the estimated need for new housing is much greater in the seven countries, where it represents 3 percent of the working age population, than in the sample industrial countries, where the ratio is only 0.9 percent. Third, the primary reason for the higher need in the seven countries is the impact of population growth; that is to say, demographic conditions alone provide a compelling reason why the housing construction sector should represent a much larger share of GDP in MED countries than in industrial countries. 
The issue can be considered in terms of a "housing transition" needed to match the demographic transition. It may be postulated that financing of housing is endogenously related to its availability: whether indirectly (in the form of rent payments) or directly (in the form of mortgage payments), households will allocate some of their income to cover their housing needs; and widespread experience with housing savings schemes shows that this is a very powerful savings incentive indeed. On this assumption, the flow of housing finance may be taken as the rate of depreciation, rent, and some mark-up, times the stock of housing. Housing investment on the other hand is driven by the growth of the working age population; the ratio of investment over the existing stock may be approximated by the sum of the growth rate of the working age population and the rate of depreciation. On this basis, the dynamics of the housing sector are closely related to the demographic transition. As the working age population expands, there is a strong acceleration in housing investment, while endogenous financing trails, creating a possible constraint on investment. As the process matures, however, housing investment levels off, while the housing stock continues to grow, so that housing-related savings catch up and eventually exceed the flow of investment. The catch is in the take-off stage, when the availability of financing is a constraint on investment; the operation of housing savings schemes and the development of mortgage markets, not the provision of public housing, is the answer.

Why is this constraint so strong, and why does need fail to result in effective demand for housing? Part of the answer is historical, rooted in the preferences of policymakers in many countries of the region for investment in industrial plant, which has depressed the housing sector of the initial funds needed for take-off. Another part lies in the poor documentation of property rights which are poorly identified and secured, so that they cannot be used as collateral to provide access to financing. "Modern market economies generate growth because widespread, formal property rights permit massive, low-cost exchange, thus fostering specialization and greater productivity...A piece of land without [a formal] title is extremely hard to market..." (de Soto (1993)). Recent work on Egypt-confirming earlier results for Peru and Haiti-illustrates this point by documenting that the acquisition of title and a construction permit to a piece of desert land would require 77 bureaucratic procedures in 31 different offices and could take some 6 to 14 years to complete (de Soto (1997)).

The link between constraints on titling and shortfalls in the housing sector is further suggested by the absence of mortgage financing in many MED countries. Major countries such as Algeria or Egypt have no mortgage market; Morocco's and Pakistan's are minimal; and Jordan stands out in this respect among regional economies in that the stock mortgages are equivalent to 10 percent of GDP. By contrast, the EU market is equivalent to 30 percent of GDP, and the U.S. market to over 60 percent (Kabbaj (1999) and Renaud (1996)). It follows that improving the documentation of property rights would not only facilitate an expansion in the housing sector but would also deepen financial intermediation in the region. 


\section{Policy IMPLICATIONS}

This paper has highlighted two key demographic features of MED countries, the high growth rate of the working age population and its rising share in the total. It has explored two immediate consequences of these conditions, a strong and accelerating demand for employment, and a large unsatisfied demand for housing. It has suggested that individually and, even more so, jointly, these consequences should be seen as opportunities as much as challenges: the demand for employment and the demand for housing can be met, provided government policy sets the stage for moderate gains in total factor productivity-or at least averts the large losses experienced by some countries in the past-and provided in particular that a major effort is made to improve the documentation of property rights. These conclusions owe their specificity to the demographic conditions of the region; otherwise they are quite in keeping with mainstream developments in growth theory: "In the long run, initial conditions and expansion of factor inputs still play a role; but the magnitude of such factor expansion, the efficiency with which factors are employed, and the long-term technological developments which also increase efficiency depend very much on policy. Good policy includes an effective legal support of property rights..." (IMF (1998)).

There are many facets to "good policy" in this context, which have been detailed, in the MED context, in recent contributions (Chabrier (1998) and Nashashibi (1999)). Let it suffice here to focus on several quantifiable indicators:

- $\quad$ MED countries are not, as a rule, seen as secure locations by foreign investors and there is little reason to believe that domestic investors would see things differently. Only 6 of the 24 MED countries, all of them members of the Gulf Cooperation Council, ranked among the top 40 ratings of Institutional Investor in September 1990; only 4 of these remained in the list of September 1998. Similarly, only four Gulf countries and Morocco and Jordan ranked above the median in a composite index of economic security, developed from standard sources, in 1995 (Fabricius (1998)). These are highly significant indicators, because the need for economic security, of which the need for proper documentation of property rights is a main component, is not confined to real estate: it encompasses all aspects of economic activity, including notably, the creation of new businesses (Tanzi (1997)).

- The average external tariff rate for MED countries in 1998 was 18.2 percent, second only to that of African countries ( 20 percent) and well above the world average (14.1 percent); 10 of the 24 countries had trade restrictiveness ratings of 7 or above, on the IMF scale, a proportion twice as large as the world average (Sharer (1998)). This again is significant, because trade distortions are a primary cause of slow or negative TFP growth.

- But the number of MED countries which have adopted the IMF Article VIII, thereby renouncing exchange restrictions for current account purposes, has risen from 7 in 1990 to 15 in 1999. This is also highly significant because the imposition of exchange restrictions is universally correlated with a regulatory environment which does not offer a level playing field to all market participants (and as such is insecure); provides heavy capital subsidies to 
public enterprises (and as such includes an anti-labor bias); and supports a distorted price structure with an overvalued exchange rate (which further prevents adjustment of the labor market to full employment).

There is little doubt, on balance, taking into account trends in privatization and reform of the financial sector, that the region has made significant progress in the past decade to establish a level playing field and support the development of a market economy. It remains true, however, that in many countries, overvalued exchange rates, subsidized interest rates and energy prices, and preferential tariffs on the impact of capital goods, continue to reduce the cost of capital and energy relative to labor. Higher rates of growth in the Middle East can indeed be achieved but they will require the removal of key economic distortions, an effective government support for a market-based economy, and-above all perhaps - betterdefined and enforced property rights. 
Table 1. Selected Regions: Key Population Data, 1970, 2000, 2015

\begin{tabular}{|c|c|c|c|c|c|}
\hline & \multicolumn{3}{|c|}{ Levels in Millions } & \multicolumn{2}{|c|}{$\begin{array}{c}\text { Annual Growth Rates } \\
\text { in Percent }\end{array}$} \\
\hline & 1970 & 2000 & 2015 & $1970-2000$ & $2000-15$ \\
\hline $\begin{array}{l}\text { World } \\
\text { of which: }\end{array}$ & 3,676 & 6,055 & 7,103 & 1.70 & 1.07 \\
\hline $0-14$ & 1,369 & 1,814 & 1,804 & 0.94 & -0.04 \\
\hline $15-64$ & 2,085 & 3,827 & 4,739 & 2.05 & 1.43 \\
\hline $\begin{array}{l}\text { European Union (15 countries) } \\
\text { of which: }\end{array}$ & 340 & 376 & 371 & 0.34 & -0.08 \\
\hline $0-14$ & 84 & 63 & 54 & -0.95 & -0.97 \\
\hline $15-64$ & 215 & 252 & 245 & 0.53 & -0.19 \\
\hline $\begin{array}{l}\text { MED countries } \\
\text { of which: }\end{array}$ & 223 & 524 & 721 & 2.88 & 2.15 \\
\hline $\begin{array}{l}0-14 \\
15-64\end{array}$ & $\begin{array}{l}101 \\
115\end{array}$ & $\begin{array}{l}205 \\
300\end{array}$ & $\begin{array}{l}242 \\
449\end{array}$ & $\begin{array}{l}2.39 \\
3.25\end{array}$ & $\begin{array}{l}1.11 \\
2.72\end{array}$ \\
\hline of which: & & & & & \\
\hline $\begin{array}{l}\text { Arab Countries } \\
\text { of which: }\end{array}$ & 122 & 281 & 385 & 2.82 & 2.12 \\
\hline $0-14$ & 55 & 107 & 129 & 2.24 & 1.25 \\
\hline $15-64$ & 63 & 164 & 240 & 3.24 & 2.57 \\
\hline $\begin{array}{l}\text { PAI 1/ } \\
\text { of which: }\end{array}$ & 101 & 243 & 336 & 2.97 & 2.16 \\
\hline $0-14$ & 46 & 98 & 113 & 2.55 & 0.95 \\
\hline $15-64$ & 52 & 136 & 210 & 3.26 & 2.91 \\
\hline
\end{tabular}

Source: World Development Report database, World Bank 1999

1/ Pakistan, Afghanistan, and Iran 
Table 2. Selected Regions: Age Structure of the Population, 1970, 2000, 2015

\begin{tabular}{|c|c|c|c|c|c|}
\hline & \multicolumn{3}{|c|}{$\begin{array}{c}\text { Share of Working Age Population } \\
\text { (In percent) }\end{array}$} & \multicolumn{2}{|c|}{$\begin{array}{l}\text { Demographic Gift } 1 / \\
\text { (In percent per annum) }\end{array}$} \\
\hline & 1970 & 2000 & 2015 & $1970-2000$ & $2000-15$ \\
\hline World & 57.1 & 63.2 & 66.7 & 0.34 & 0.36 \\
\hline EU (15 countries) & 63.2 & 67.0 & 66.0 & 0.19 & -0.12 \\
\hline $\begin{array}{l}\text { MED countries } \\
\text { of which: }\end{array}$ & 51.6 & 57.2 & 62.3 & 0.36 & 0.56 \\
\hline Arab countries & 51.6 & 58.4 & 62.3 & 0.41 & 0.44 \\
\hline PAI & 51.5 & 56.0 & 62.5 & 0.28 & 0.73 \\
\hline
\end{tabular}

Source: Data in Table 1

1/ Growth rate of working age population, minus that of total population. 
Table 3. Selected MED Countries: Employment, 1973-2015

(Annual growth rates in percent)

\begin{tabular}{|c|c|c|c|c|c|c|c|}
\hline & \multicolumn{5}{|c|}{ Employment Growth } & \multirow{2}{*}{\multicolumn{2}{|c|}{ Unemployment Rate (in percent) }} \\
\hline & & & & Of which & & & \\
\hline & $\begin{array}{l}\text { Estimated } \\
1973-19941 /\end{array}$ & $\begin{array}{l}\text { Required } \\
2000-15\end{array}$ & $\begin{array}{c}\text { Working age } \\
\text { population }\end{array}$ & $\begin{array}{l}\text { Participation } \\
\text { rate } 3 /\end{array}$ & $\begin{array}{l}\text { Unemployment } \\
\text { reduction } 3 /\end{array}$ & $\begin{array}{l}\text { Latest available } \\
\text { official estimate }\end{array}$ & $\begin{array}{l}\text { Targeted } \\
2000-15\end{array}$ \\
\hline Algeria & 3.2 & 5.0 & 2.7 & 1.0 & 1.3 & 28.0 & 14.0 \\
\hline Egypt & 1.4 & 3.6 & 2.2 & 1.0 & 0.4 & 12.0 & 6.0 \\
\hline Iran & 2.6 & 4.1 & 2.5 & 1.0 & 0.6 & 14.0 & 7.0 \\
\hline Jordan & n.a. & 4.4 & 2.8 & 1.0 & 0.6 & 15.0 & 7.0 \\
\hline Morocco & 3.6 & 3.6 & 2.1 & 1.0 & 0.5 & 13.0 & 6.0 \\
\hline Pakistan & 2.5 & 4.1 & 3.1 & 1.0 & 0.0 & 6.0 & 6.0 \\
\hline Tunisia & 2.3 & 3.6 & 3.1 & 1.0 & 0.6 & 15.0 & 7.0 \\
\hline
\end{tabular}

Sources: Employment, 1975-2000: ILO Yearbook, various years, except Iran: national estimates; working age population projections: World Development Report Database, World Bank, 1999.

1/ Or closest available.

2/ Level in percent of labor force.

$3 /$ Contribution in points to the desired increase in employment. 
Table 4. Selected MED Countries: The Augmented Demographic Gift

(Growth rates in percent per annum)

\begin{tabular}{|c|c|c|c|c|c|c|}
\hline & $\begin{array}{c}\text { Employment } \\
\text { (1) }\end{array}$ & $\begin{array}{l}\text { Population } \\
\text { (2) }\end{array}$ & $\begin{array}{c}\text { Augmented } \\
\text { Demographic } \\
\text { Gift } \\
(3)=(1)-(2)\end{array}$ & $\begin{array}{l}\text { Real GDP } \\
\text { Growth } \\
(4)\end{array}$ & $\begin{array}{l}\text { Real GDP } \\
\text { per } \\
\text { Employee } \\
(5)=(4)-(1)\end{array}$ & $\begin{array}{l}\text { Real GDP } \\
\text { per Capita } \\
(6)=(5)+(3)\end{array}$ \\
\hline \multicolumn{7}{|c|}{ 1973-1994 Estimates } \\
\hline Algeria & 3.2 & 2.7 & 0.5 & 2.9 & -0.3 & 0.2 \\
\hline Egypt & 1.4 & 2.2 & -0.8 & 5.6 & 4.2 & 3.4 \\
\hline Iran & 2.6 & 2.9 & -0.3 & 0.3 & -2.3 & -2.6 \\
\hline Jordan & n.a. & 3.9 & n.a. & 6.6 & n.a. & 2.7 \\
\hline Morocco & 3.6 & 2.1 & 1.5 & 4.4 & 0.8 & 2.3 \\
\hline Pakistan & 2.5 & 3.0 & -0.5 & 5.9 & 3.4 & 2.9 \\
\hline Tunisia & 2.3 & 2.2 & 0.1 & 4.5 & 2.2 & 2.3 \\
\hline \multicolumn{7}{|c|}{ 2000-2015 Projections } \\
\hline Algeria & 5.0 & 2.1 & 2.9 & 6.5 & 1.5 & 4.4 \\
\hline Egypt & 3.6 & 1.5 & 2.1 & 5.1 & 1.5 & 3.6 \\
\hline Iran & 4.1 & 1.7 & 2.4 & 5.6 & 1.5 & 3.9 \\
\hline Jordan & 4.4 & 2.3 & 2.1 & 5.9 & 1.5 & 3.6 \\
\hline Morocco & 3.6 & 1.5 & 2.1 & 5.1 & 1.5 & 3.6 \\
\hline Pakistan & 4.1 & 2.4 & 1.7 & 5.6 & 1.5 & 3.2 \\
\hline Tunisia & 3.6 & 1.3 & 2.3 & 5.1 & 1.5 & 3.8 \\
\hline
\end{tabular}

Sources: Employment from Table 3; population and working age population from World Development Report Database, World Bank, 1999; historical data on real GDP growth from Collins and Bosworth (1996), for 2000-2015: real GDP and real GDP per capita derived from the target of 1.5 percent annual growth in real GDP per employee. 
Table 5. Selected MED Countries: Total Factor Productivity Growth Requirements

(Annual growth rates in percent)

\begin{tabular}{|c|c|c|c|c|c|c|c|}
\hline & \multirow[b]{2}{*}{ TFP Growth } & \multicolumn{4}{|c|}{ Of which: contributions $1 /$ of: } & \multirow[b]{2}{*}{$\begin{array}{l}\text { Estimated } \\
\text { ICOR }\end{array}$} & \multirow{2}{*}{$\begin{array}{c}\text { Memo Item: } \\
\text { Investment } \\
\text { Ratio (I/Y) } \\
\text { Level } \\
\text { (in percent) }\end{array}$} \\
\hline & & $\begin{array}{l}\text { Real } \\
\text { wage }\end{array}$ & $\begin{array}{c}\text { Employ- } \\
\text { ment }\end{array}$ & $\begin{array}{c}\text { Human } \\
\text { capital }\end{array}$ & $\begin{array}{c}\text { Physical } \\
\text { capital }\end{array}$ & & \\
\hline \multicolumn{8}{|c|}{ I. 1973-1994 Estimate } \\
\hline Algeria & -3.4 & -0.3 & 1.1 & -0.6 & -3.6 & 12.5 & 36.0 \\
\hline Egypt & 2.9 & 4.2 & 0.5 & -0.3 & -1.5 & 3.7 & 21.0 \\
\hline Iran & -3.4 & -2.3 & 0.9 & -0.7 & -1.3 & 56.9 & 19.0 \\
\hline Jordan & 0.0 & 0.0 & n.a. & 0.9 & -2.5 & 4.3 & 28.0 \\
\hline Morocco & -0.2 & 0.8 & 1.3 & -0.2 & -2.0 & 5.5 & 24.0 \\
\hline Pakistan & 3.2 & 3.4 & 0.9 & -0.1 & -1.0 & 2.9 & 17.0 \\
\hline Tunisia & -0.2 & 2.2 & 0.8 & -0.6 & -2.7 & 6.4 & 29.0 \\
\hline \multicolumn{8}{|c|}{ II. $2000-2015$ Projections } \\
\hline Algeria & 0.2 & 1.5 & 1.8 & -0.6 & -2.5 & 4.3 & 28.0 \\
\hline Egypt & 0.0 & 1.5 & 1.3 & -0.3 & -2.5 & 5.5 & 28.0 \\
\hline Iran & -0.3 & 1.5 & 1.4 & -0.7 & -2.5 & 5.0 & 28.0 \\
\hline Jordan & -0.4 & 1.5 & 1.5 & -0.9 & -2.5 & 4.8 & 28.0 \\
\hline Morocco & 0.0 & 1.5 & 1.3 & -0.2 & -2.5 & 5.5 & 28.0 \\
\hline Pakistan & 0.3 & 1.5 & 1.4 & -0.1 & -2.5 & 5.0 & 28.0 \\
\hline Tunisia & -0.3 & 1.5 & 1.3 & -0.6 & -2.5 & 5.5 & 28.0 \\
\hline
\end{tabular}

Sources: 1975-2000: real wage growth is real GDP per employee, from Table 4; employment from Table 3; human capital growth, and investment output ratio from Collins and Bosworth, 1996. Physical capital growth ICOR and TFP are calculated. 2000-2015: assumptions and calculations as described in the text. TFP growth calculated from equation (4).

1/ Assumes labor share of 0.65 , capital output ratio of 2.5 , and depreciation ratio of 4 percent.

$2 /$ Working age population weights. 
Table 6. Selected Countries: Key Housing Data, 2000

(In million housing units)

\begin{tabular}{|c|c|c|c|c|c|c|c|c|}
\hline \multirow[b]{2}{*}{ Existing Stock } & \multicolumn{2}{|c|}{$\begin{array}{l}\text { Working Age } \\
\text { Population } 1 /\end{array}$} & \multirow{2}{*}{$\begin{array}{l}\text { Desired } \\
\text { Housing } \\
\text { Stock 2/ }\end{array}$} & \multicolumn{3}{|c|}{ Desired Flow } & & \multirow{2}{*}{$\begin{array}{c}\text { Average } \\
\text { Actual } \\
\text { Flow }\end{array}$} \\
\hline & (million) & $\begin{array}{l}\text { Growth rate } \\
\text { (percent) }\end{array}$ & & Replacement 3/ & $\begin{array}{c}\text { Shortfall } \\
\text { Reduction } 4 /\end{array}$ & $\begin{array}{l}\text { Population } \\
\text { Growth 5/ }\end{array}$ & Total & \\
\hline
\end{tabular}

\begin{tabular}{|c|c|c|c|c|c|c|c|c|c|c|c|}
\hline Algeria & 4.0 & $(1997)$ & 18.2 & $(2.7)$ & 10.9 & 0.1 & 0.1 & 0.3 & 0.5 & 0.1 & (1995-97) \\
\hline Egypt & 12.6 & (1995) & 38.7 & $(2.2)$ & 23.2 & 0.3 & 0.3 & 0.5 & 1.1 & 0.2 & $(1986-92)$ \\
\hline Iran & 11.2 & (1998) & 40.2 & (2.5) & 24.1 & 0.3 & 0.3 & 0.8 & 1.4 & 0.3 & $(1995--97)$ \\
\hline Jordan & 0.6 & (1996) & 2.8 & $(2.5)$ & 1.7 & $\ldots$ & $\ldots$ & $\ldots$ & 0.1 & $\cdots$ & \\
\hline Morocco & 4.1 & (1994) & 18.0 & $(2.1)$ & 10.8 & 0.1 & 0.1 & 0.2 & 0.4 & 0.1 & $(1995-97)$ \\
\hline Pakistan & 20.0 & $(1997)$ & 81.8 & & 49.0 & 0.5 & 0.6 & 1.5 & 2.6 & 0.3 & (1997) \\
\hline Tunisia & 1.5 & $(1990)$ & 6.2 & $(2,0)$ & 3.7 & $\ldots$ & $\ldots$ & 0.1 & 0.1 & 0.1 & $(1995-96)$ \\
\hline \multicolumn{12}{|l|}{ Total seven MED } \\
\hline countries & 62.0 & $(\ldots)$ & 205.9 & (..) & 123.4 & 1.3 & 1.4 & 3.4 & 6.1 & 1.1 & $(\ldots)$ \\
\hline France & 28.2 & (1996) & 38.9 & $(0.2)$ & 23.3 & 0.3 & 0.0 & 0.1 & 0.4 & 0.4 & $(1995-96)$ \\
\hline Italy & 19.7 & (1991) & 39.2 & $(-0.6)$ & 23.5 & 0.2 & 0.1 & -0.1 & 0.2 & 0.2 & (1993-94) \\
\hline United Kingdom & 23.6 & (1991) & 38.2 & $(\ldots)$ & 22.9 & 0.2 & 0.0 & 0.0 & 0.2 & 0.2 & (1995-96) \\
\hline United States & 102.3 & $(1990)$ & 181.0 & $(0.7)$ & 109.0 & 1.0 & 0.0 & 0.8 & 1.8 & 1.4 & (1995-96) \\
\hline Total four & & & & & & & & & & & \\
\hline industrial countries & 173.8 & $(\ldots)$ & 297.3 & $(0.4)$ & 178.4 & 1.7 & 0.1 & 0.8 & 2.7 & 2.2 & \\
\hline
\end{tabular}

Sources: United Nations: ECE, Trends in Europe and North America, 1988/99; Compendium of Human Settlements Statistics, 1995; Housing and

Building Statistics for Europe and North America 1998/99; and staff estimates.

1/ Estimated working age population in year 2000 and average annual growth rate, 2000-2015. (Source: World Development Report database).

2/ Sixty percent of estimated working age population in year 2000 .

3/ One-fortieth (1/40) of existing stock for MED countries, 1 percent for industrial countries.

4/ Elimination of the gap between actual and desired stock over a 30-year period at a steady geometric rate; no correction is made for the discrepancies

in dates of estimates of existing stock.

5/ Growth rate of the working age population times the desired housing stock. 


\section{References}

Al-Qudsi, S., R. Assaad, and R. Shaban, 1995, "Labor Markets in the Arab Countries," International Labor Review 134 (1), pp. 65-81.

Barlow, R. ,1994, "Population Growth and Economic Growth: Some More Correlations," Population and Development Review, 20, pp. 153-165.

Bloom, D. and J. Williamson, 1997, "Demographic Transitions and Economic Miracles in Emerging Asia," Chapter 3 in Emerging Asia: Changes and Challenges (Manila: Asian Development Bank).

1998, "Demographic Transitions and Economic Miracles in Emerging Asia," World Bank Economic Review (forthcoming).

Brander, J. and S. Dowrick, 1994, "The Role of Fertility and Population in Economic Growth: Empirical Results from Aggregate Cross-National Data," Journal of Population Economics 7, pp. 1-25.

Chabrier, Paul (1998), 1998, "Middle Eastern and North American Countries' Need to Accelerate Process of Economic Integration" IMF Survey July 6, 1998.

Collins, Susan M. and B.P. Bosworth, 1996, "Economic Growth in East Asia: Accumulation versus Assimilation," Brookings Papers on Economic Activity, Vol 2.

Crafts, Nicolas, 1998, "East Asian Growth Before and After the Crisis," WP/98/137 (Washington, D.C.: International Monetary Fund).

de Soto, Hernandez, 1997, Dead Capital and the Poor in Egypt, Cairo, Egyptian Center for Economic Studies. 1993, “The Missing Ingredient" The Economist, September 11, 1993.

Fabricius, Michael, 1998, The Impact of Economic Security on Bank Deposits and Investment, WP/98/98 (Washington, D.C.: International Monetary Fund).

Guasch, J. Luis, 1999, Labor Market Reform and Job Creation: The Unfinished Agenda in Latin America and Caribbean Countries (Washington, D.C.: World Bank).

International Monetary Fund, 1998, "Growth Experience in Transition Economies," SM/98/228 (Washington, D.C.: International Monetary Fund).

Kabbaj, S., 1999, "Housing Sector in the Middle East," mimeo, International Monetary Fund, Middle Eastern Department. 
Kelley, A., and R. Schmidt, 1995, "Aggregate Population and Economic Growth Correlations: The Role of the Components of Demographic Change," Demography 32, pp. 543-55.

Kelley, A.C., 1988, "Economic Consequences of Population Growth in the Third World," Journal of Economic Literature 27, pp. 1685-728.

Lindh, T. and B. Malmberg, 1999, "Age Structure Effects and Growth in the OECD, 1950-90," Journal of Population Economics 12 (3), pp. 431-449.

Mankiw, G. and D. Weil, 1989, "The Baby Boom, The Baby Bust, And The Housing Market," Regional Science and Urban Economics 19, pp. 235-58.

Mohie el-Din, Amr, 1982, Income Distribution and Basic Needs in Urban Egypt, Cairo Papers in Social Science 5, Monograph 3.

Nashashibi, Karim, 1999, "The Social Impact of Free Trade in the Euro-Mediterranean Region," address to Wilton Park Conference on the Social Impact of Free Trade in the Euro Mediterranean Region, Malta, November 8-11, 1999.

Page, J. and L. Van Gelder, 1999, "Institutions, Investment and Growth in the Middle East and North Africa," Paper presented at the AFSED/AMF/IMF Joint Seminar in Kuwait.

Pissarides, C., 1993, "Labor Markets in the Middle East and North Africa, "World Bank Discussion Paper Series No. 5, Washington, D.C.

Radelet, S., J. Sachs and J. Lee, 1997, "Economic Growth in Asia," Chapter 2 in Emerging Asia: Changes and Challenges (Manila, Philippines: Asian Development Bank).

Renaud, Bertrand, 1996, "Strategies to Develop Mortgage Markets in Liberalizing Economies" in Globalization and Housing Industries, Hee-Soo Chung and Dong-Sung Lee eds., Korea Housing Institute (Nanam Publishing House).

Richards, A. and J. Waterbury, 1996, A Political Economy of the Middle East (Boulder: Westview Press).

Sharer, R., and others, 1998, "Trade Liberalization in IMF-Supported Program, World Economic and Financial Surveys (Washington, D.C.: International Monetary Fund).

Sternlieb, G. and J. Hughes, 1986, "Demographics and Housing in America," Population Bulletin 41, pp. 1-34. 
Tanzi, Vito, 1997, The Changing Role of the State in the Economy: An Historical Perspective, WP/97/114 (Washington, D.C.: International Monetary Fund).

Williamson, J. and T. Yousef, 1999, "Demographic Transitions and Economic Performance in the Middle East and North Africa," forthcoming in I. Sirageldin, ed., Population Challenges in the Middle East and North Africa.

World Bank, 1994, The Democratic and Popular Republic of Algeria: Country Economic memorandum, the Transition to a Market Economy, Washington, D.C.

Yousef, T., 1998, "Demography, Capital Dependency and Growth in MENA," ERF Working Paper 9801, Cairo, Egypt. 